\title{
Analysis of Fire Risk Associated with Photovoltaic Power Generation System
}

\author{
Guomin Zhao $\mathbb{D}^{1}{ }^{1}$ Min Li $\mathbb{D}^{,}{ }^{1}$ Lv Jian, ${ }^{1}$ Zhicheng He, ${ }^{1}$ Jin Shuang, ${ }^{1}$ Sun Yuping, \\ Qingsong Zhang, ${ }^{2}$ and Liu Zhongxian ${ }^{1,3}$
}

${ }^{1}$ School of Energy and Safety Engineering, Tianjin Chengjian University, Tianjin 300384, China
${ }^{2}$ Economics and Management College, Civil Aviation University of China, Tianjin 300300, China
${ }^{3}$ Tianjin Key Laboratory of Civil Structure Protection and Reinforcement, Tianjin 300384, China

Correspondence should be addressed to Min Li; 13032285773@163.com

Received 18 January 2018; Revised 27 March 2018; Accepted 8 April 2018; Published 30 April 2018

Academic Editor: Kirk Hatfield

Copyright $(92018$ Guomin Zhao et al. This is an open access article distributed under the Creative Commons Attribution License, which permits unrestricted use, distribution, and reproduction in any medium, provided the original work is properly cited.

Because of increasing energy consumption and severe air pollution in China, solar photovoltaic power generation plants are being deployed rapidly. Owing to various factors such as technology, construction, and imperfection of construction standards, solar photovoltaic systems have certain fire risks. This paper focuses on the fire risks of building-integrated solar photovoltaic buildings, as well as temperature and heat flow density near a photovoltaic system in a fire. Based on FDS simulation results, the influence of different building fires on photovoltaic systems is analysed. It is found that the influence of fire on photovoltaic systems installed on a building with a flat roof is stronger than that on a system installed on a building with a sloping roof; the influence of fire on a photovoltaic system installed on a building with external wall thermal insulation is stronger than that on a system installed on a building without such insulation; and in the presence of a skylight, a photovoltaic system installed on a building with a sloping roof is more dangerous.

\section{Introduction}

Given the difficulty in reconciling the contradiction between the limitations of conventional energy sources such as oil and coal and the expanding energy demand, all countries in the world have been promoting the development of photovoltaic systems. As a result, the photovoltaic industry has grown rapidly under the support of various national policies [1]. Specifically, photovoltaic buildings as a typical form of photovoltaic systems have developed rapidly $[2,3]$. However, the development of photovoltaic buildings creates huge pressures in terms of firefighting, especially at the present stage, where technology is in a relatively nascent stage and relevant specifications are lacking. Therefore, photovoltaic buildings are potential fire hazards. First, photovoltaic power generation systems may undergo spontaneous combustion. Second, photovoltaic systems installed in buildings are threatened by building fires. Finally, because current flows through photovoltaic systems, a fire in such systems is difficult to extinguish. For the above reasons, PV systems are frequently susceptible to fire $[4,5]$. In view of this, it is important to focus on the security of photovoltaic systems, especially distributed photovoltaic systems and photovoltaic buildings.

The composition of photovoltaic building systems is shown in Figure 1. Such systems generally consist of a photovoltaic array (which is composed of low iron tempered, EVA FILM, solar power chip, and TPT dorsal membrane), combiner boxes, inverter, and transformer. The risk of spontaneous combustion of photovoltaic systems is caused by the hot spot effect.

DC arc and other reasons have been greatly mitigated with the maturity of photovoltaic technology $[6,7]$. Photovoltaic arrays of photovoltaic power generation systems are mainly installed on the roof of a building, which can be threatened by building fire. Because there is no specific fire prevention code for photovoltaic buildings, exiting photovoltaic buildings or those under construction are designed in 


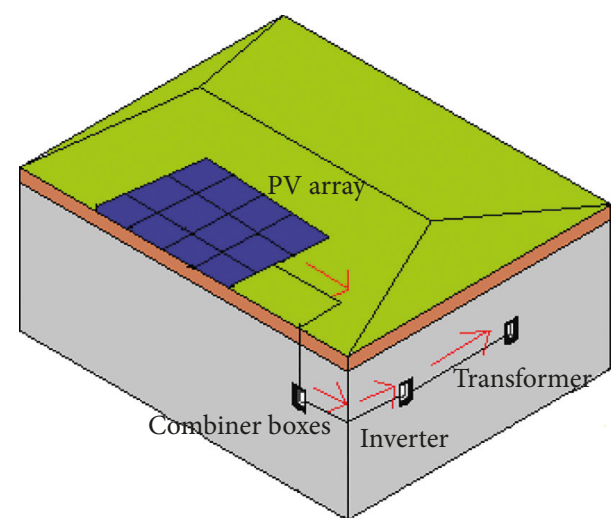

FIgure 1: Photovoltaic building system.

accordance with the existing codes for fire protection. Compared with traditional buildings, the fire load of photovoltaic buildings is higher, and such buildings are more susceptible to fire owing to the addition of power generation systems. Fires of photovoltaic power generation systems are electrical fires, and it would be difficult to effectively cutoff the power supply. Moreover, water, which is the conventional firefighting medium, cannot be used to extinguish fires in photovoltaic buildings [8-10]. Furthermore, at present, the research on roof fires in China is inadequate $[11,12]$. Thus far, in China, there are no relevant specifications for roofing construction, fire protection, and standards for flame-retardant performance of roof waterproofing and thermal insulation materials. Roof waterproofing and thermal insulation materials tend to be rigid combustible materials such as polyurethane foam [13], and they are hidden dangers in the event of a roof fire. To sum up, photovoltaic buildings can catch fire easily.

Until now, great importance has been attached to the power generation efficiency of the photovoltaic systems, but few researchers have focused on the safety aspects of these systems, especially photovoltaic buildings. Once a building fire starts, photovoltaic power generation systems will be exposed to great danger; for this reason, in the present study, the authors apply FDS to simulate indoor fires, building roof fire, and other types of fire scenarios and analyse the threats posed by different types of building fires to solar photovoltaic power generation systems by detecting the temperature field and heat flow density of certain areas.

\section{Theoretical Model}

According to Yang et al. [4], two factors pose dangers to photovoltaic systems, namely, temperature and heat flow density. To determine temperature and heat flow density, the first step in calculation is to set up a control equation. The control equation is a mathematical description of the law of physical conservation.

2.1. Temperature. According to the Boussinesq approximation, the temperature term can be expressed as follows:

$$
\begin{aligned}
T & =T_{0}(t)(1+\widetilde{T}), \\
\rho & =\rho_{0}(t)(1+\widetilde{\rho}), \\
p(r, t) & =p_{0}(t)-\rho_{0}(t) g z+\widetilde{p}(\widetilde{r}, t), \\
P_{0} \int_{\delta \Omega} u d S+\frac{V}{\gamma} \frac{d p_{0}}{d t} & =\frac{\gamma-1}{\gamma}\left(\int_{\Omega} q d V+\int_{\delta \Omega} k \nabla T d S\right), \\
P_{0} & =\rho_{0} R T_{0}, \\
\frac{\rho_{0}}{\rho_{\infty}} & =\left(\frac{P_{0}}{P_{\infty}}\right)^{1 / \gamma}, \\
\frac{\partial T}{\partial t}+u \nabla \widetilde{T} & =(1+\widetilde{T})\left[\nabla u+\frac{d p_{0}}{d t}\right], \\
\frac{\partial u}{\partial t}-u \times \omega+\nabla H & =\frac{1}{\rho}\left[\left(\rho-\rho_{\infty}\right) g+f+\nabla \tau\right], \\
\nabla 2 H & =-\frac{\partial(\nabla u)}{\partial t}-\nabla F,
\end{aligned}
$$

where $H$ is the total pressure,

$$
\begin{aligned}
& H=\frac{P}{\rho_{0}}+\frac{|u|^{2}}{2}, \\
& F=-u \times \omega-\frac{1}{\rho}\left[\left(\rho-\rho_{\infty}\right) g+f+\nabla \tau\right] .
\end{aligned}
$$

2.2. Heat Flow Density. For the vast majority of FDS applications, the "mixed is burnt" assumption is adequate to model the reaction system, and the mean chemical source term for fuel can be modelled using the eddy dissipation concept (EDC) put forth by Magnussen and Hjertager $[14,15]$ :

$$
\dddot{m}_{\mathrm{F}}=-\rho \frac{\min \left(Z_{\mathrm{F}}, \dddot{Z}_{\mathrm{A}} / s\right)}{\tau_{\text {mix }}},
$$

where $Z_{\mathrm{F}}$ and $\dddot{Z}_{\mathrm{A}}$ are the lumped mass fractions of fuel and air, respectively, and $s$ is the mass stoichiometric coefficient of air. The quantity $\tau_{\text {mix }}$ is the timescale for mixing, which must be modelled. The EDC model, therefore, states that the rate of fuel consumption is proportional to both the local limiting reactant concentration and the local rate of mixing.

Heat release per unit volume is calculated by summing the products of the mass production rates of various species with their respective heats of formation:

$$
\dddot{q} \equiv-\sum_{\alpha} \dddot{m}_{\alpha} \nabla h_{f, \alpha} \text {. }
$$




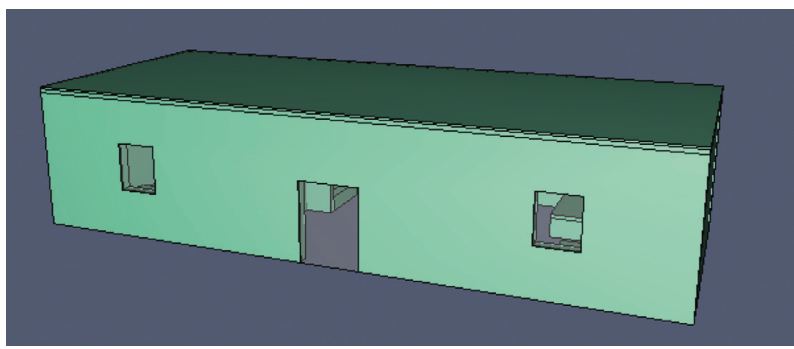

Figure 2: Flat roof building model.

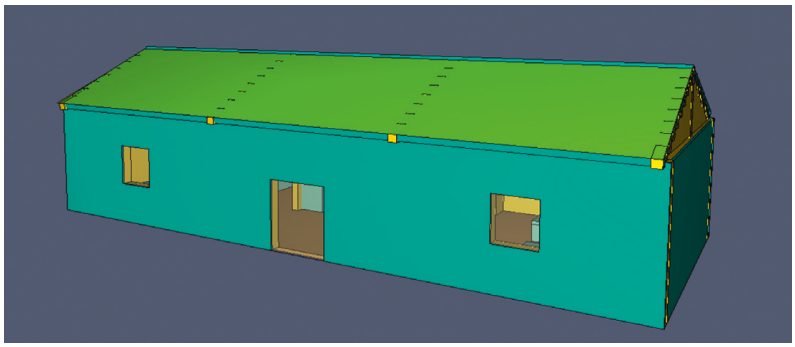

FIGURE 3: Sloping roof building model.

TABLE 1: Fire scenarios.

\begin{tabular}{|c|c|c|c|c|c|c|c|c|}
\hline \multirow{2}{*}{ Type } & \multicolumn{8}{|c|}{ Fire scenarios } \\
\hline & Case 1 & Case 2 & Case 3 & Case 4 & Case 5 & Case 6 & Case 7 & Case 8 \\
\hline Roof & Plane & Plane & Plane & Sloping, skylight & Sloping, skylight & Sloping & Sloping & Sloping \\
\hline Insulation layer & External & Internal & - & Internal & External & Internal & External & - \\
\hline Fire source & Room & Room & Roof & Room & Room & Room & Room & Roof \\
\hline
\end{tabular}

To maintain code stability, it is occasionally necessary to impose an upper bound on the local heat release rate per unit volume. A scaling analysis of pool fires by Orloff and de Ris [16] suggests that the spatial average of the heat release rate of a fire is approximately $1200 \mathrm{~kW} / \mathrm{m}^{2}$. FDS imposes a less restrictive upper bound on the local heat release rate per unit volume:

$$
\dddot{q}_{\text {upper }}=\frac{200}{\delta x}+2500 .
$$

The value of $200 \mathrm{~kW} / \mathrm{m}^{2}$ is an empirically derived upper bound on the heat release rate per unit area of a flame sheet and $\delta x$ is the characteristic cell size $(\mathrm{m})$.

\section{Simulation and Analysis}

Fire simulation involves solving unknowns (density, velocity, temperature, and pressure) in equations based on reasonable simplification and approximation of the control equations. There are considerable differences between the temperatures and heat flow densities of different photovoltaic buildings. To ensure the safety of photovoltaic systems, eight types of photovoltaic building scenarios are considered, and the temperatures and heat flow densities of eight fire scenarios are solved.
3.1. Model Building. The flat- and sloping-roofed building models are shown in Figures 2 and 3, respectively. The geometric size of the flat-roofed building is $16,000 \times 6600 \times$ $3650 \mathrm{~mm}$, thickness of its concrete walls is $250 \mathrm{~mm}$, thickness of the polyurethane wall insulation layer is $50 \mathrm{~mm}$, thickness of the concrete roof structure layer is $100 \mathrm{~mm}$, thickness of polyurethane roof waterproofing and thermal insulation layers is $50 \mathrm{~mm}$, and the building houses a few pieces of room furniture. The geometric size of the sloping-roofed building is $16,000 \times 6600 \times 3650 \mathrm{~mm}$, thickness of its concrete walls is $250 \mathrm{~mm}$, thickness of the polyurethane wall insulation layer is $50 \mathrm{~mm}$, thickness of its PVC ceiling is $20 \mathrm{~mm}$, thickness of the sloping concrete roof is $50 \mathrm{~mm}$, thickness of its polyurethane waterproofing and thermal insulation layers is $10 \mathrm{~mm}$, and an additional protective layer of ceramic tile is laid on top $[17,18]$.

3.2. Scene Setting. In this paper, eight fire scenarios, presented in Table 1, were used to simulate indoor or outdoor fire in a flat-roofed or sloping-roofed structure.

3.3. Data Detection Device Settings. Because most photovoltaic arrays are installed on the roof of buildings and the threat of building fire to photovoltaic systems depends 
mainly on the temperature field of the roof, heat flow and other factors, the authors setup six thermocouples and heat flow metres in the simulation scenarios to monitor the temperature field and heat flow on the building roof. The thermocouples and heat flow density metres on the roof of the building were distributed evenly, and their distance to the roof was $20 \mathrm{~cm}$.

3.4. Simulation Result Analysis. According to the experiments of Yang et al. [4], when the heat flow radiation intensity changes from 28 to $45 \mathrm{~kW} / \mathrm{m}^{2}$, the ignition times of solar cell panels change from 913 to $83 \mathrm{~s}$. When the temperature and heat flow density on the roof area are high, the photovoltaic systems can be ignited easily. The simulation results of the eight fire scenarios are stated below.

The authors simulated eight fire scenarios. By using the theoretical model described above, we can obtain the temperature field near the roof. The heat flow density of a roof on fire can be determined by solving (3)-(5). Due to space constraints, it is difficult to present the analysis results of the eight types of fire scenarios separately. Therefore, case 1 is taken as an example to analyse the influence of a fire on a flat roof on photovoltaic systems, and case 4 is taken as an example to analyse the influence of a fire on a sloped roof on photovoltaic systems. Finally, the influences of eight types of fire scenarios on photovoltaic systems are analysed by comparing the highest roof temperatures and heat flows in each fire scenario.

The monitoring data of case 1 are shown in Figures 4 and 5:

As shown in Figure 4, the changes in roof temperature in case 1 can be divided into three stages: the first stage is the phase from the start of the fire to $270 \mathrm{~s}$, where the roof temperature rises gradually to about $100^{\circ} \mathrm{C}$; the second stage is the phase from $270 \mathrm{~s}$ to $750 \mathrm{~s}$, during which time the roof temperature is maintained at approximately $100^{\circ} \mathrm{C}$; and the third stage is the phase from $750 \mathrm{~s}$ to the end of the simulation, during which time the roof temperature first rises sharply and then falls sharply. The roof temperatures at different locations within the roof are different, and the highest roof temperature is about $700^{\circ} \mathrm{C}$.

From Figure 5, we know that the roofing heat flows at different locations in case 1 have almost the same change tendency, that is, between $0 \mathrm{~s}$ and $750 \mathrm{~s}$; the heat flows increase very slowly; and then, they peak with a dramatic rise, followed by a sharp drop to zero. There are some differences among the roofing heat flows at different locations. The peak heat flow density is nearly $250 \mathrm{~kW} / \mathrm{m}^{2}$.

When the simulation time is $750 \mathrm{~s}$, the indoor fire spreads out of the room through the doors, windows, skylights, and other openings and ignites the roof waterproofing and insulation layers, and a naked light appears on the roof, which leads to a sharp increase in the temperature of heat flow on the roof. The temperatures of most parts of the roof were higher than $500^{\circ} \mathrm{C}$, and the heat flow densities were higher than $150 \mathrm{~kW} / \mathrm{m}^{2}$. As a consequence, we can see the trends of changes in roof temperatures and heat flows described above.

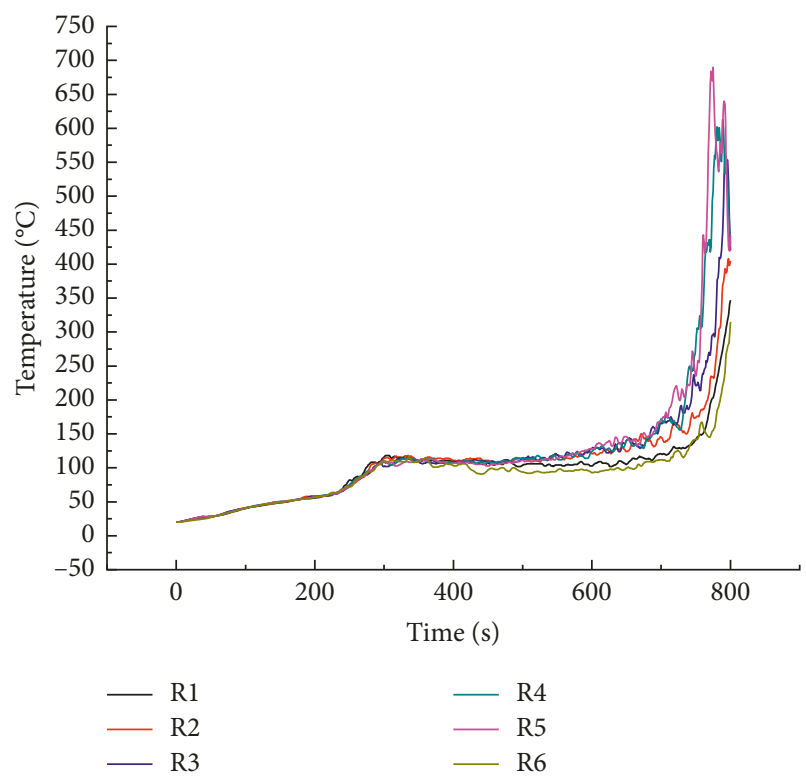

Figure 4: Temperature in case 1.

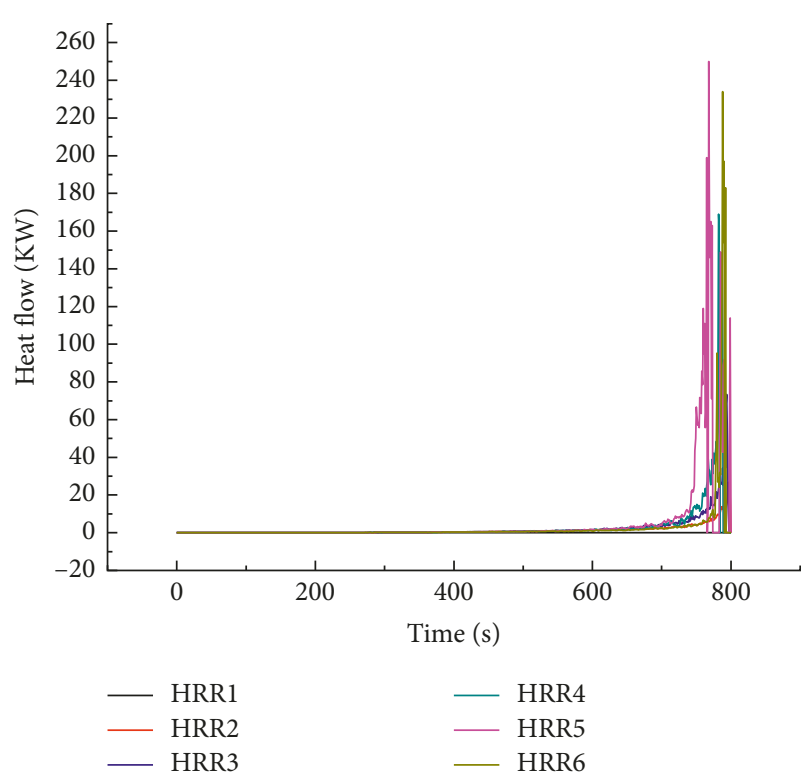

Figure 5: Heat flow density in case 1.

In case 2, the roof waterproofing and insulation layers burned out within $150 \mathrm{~s}$, and roof temperature in the former $150 \mathrm{~s}$ rose rapidly, with the roof top temperature reaching $1000^{\circ} \mathrm{C}$; it decreased gradually thereafter. Heat flow density increased sharply at $150 \mathrm{~s}$, and the maximum heat flow density on the roof was close to $300 \mathrm{~kW} / \mathrm{m}^{2}$, which decreased to 0 .

The monitoring data of case 3 are shown in Figures 6 and 7.

As can be seen in Figure 6, the trend of change in roof temperature is the same. From beginning to the simulation time of $200 \mathrm{~s}$, the roof temperature rises gradually and reaches its peak at $200 \mathrm{~s}$, after which it remains stable. The 


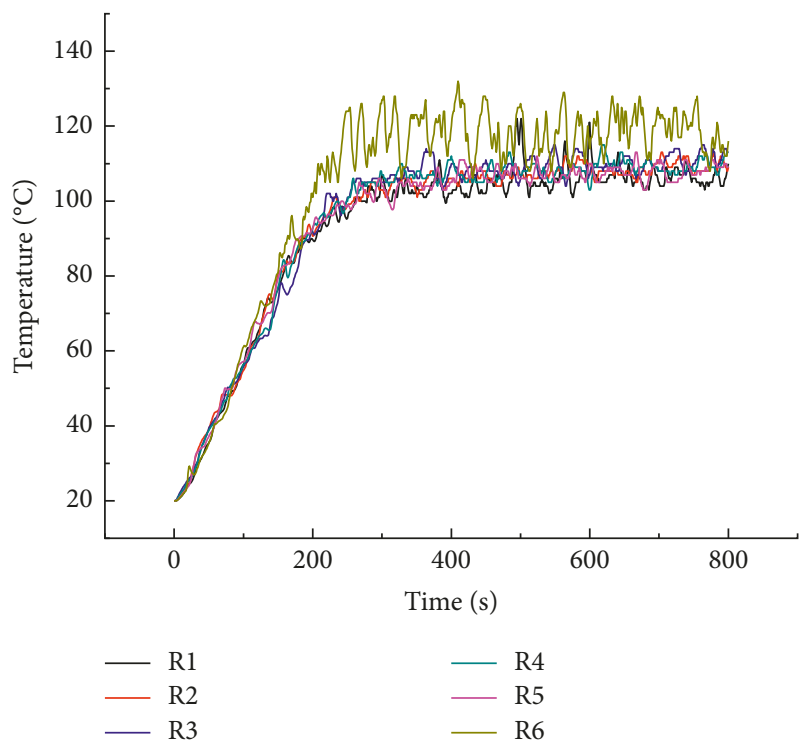

Figure 6: Temperature in case 3.

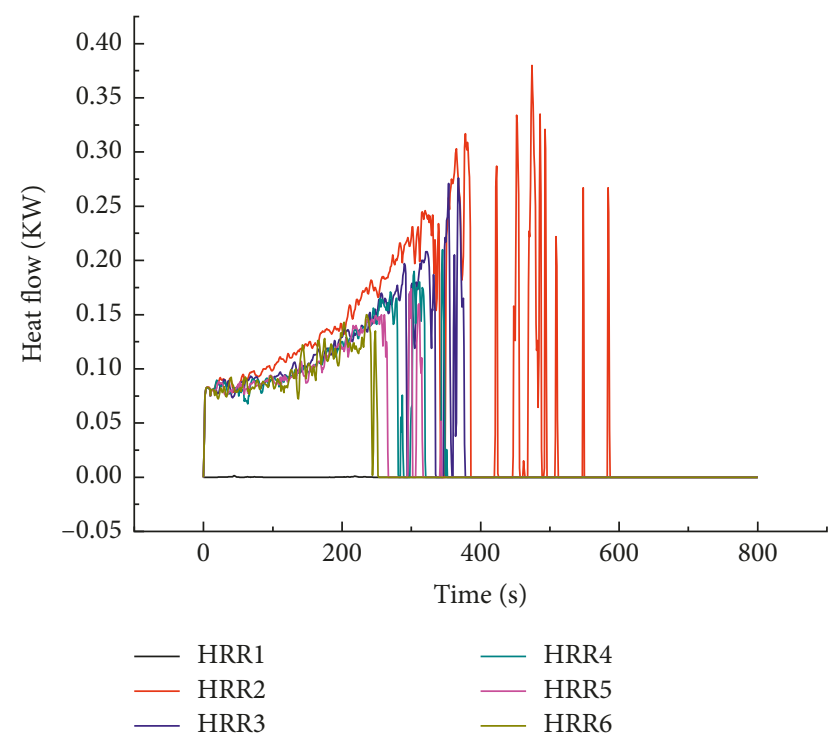

Figure 7: Heat flow density in case 3.

highest temperatures of most areas of the roof are less than $100^{\circ} \mathrm{C}$.

We can see from Figure 7 that the heat flow densities on the roof in case 3 are close to 0 .

The monitoring data of case 4 are shown in Figures 8 and 9.

Figure 8 shows the trend of change in roofing temperature in case 4 . From $0 \mathrm{~s}$ to $750 \mathrm{~s}$, the roof temperature rises; from $300 \mathrm{~s}$ to $420 \mathrm{~s}$, the roof temperature rises rapidly; and at $750 \mathrm{~s}$, the roof temperature peaks at $350^{\circ} \mathrm{C}$.

Figure 9 shows that the trend of heat flow density throughout the area around the roof is consistent. The change in heat flow density tends to zero. Specifically, the heat flows of HRR1 and HRR4 start increasing at 420 s, peak at $720 \mathrm{~s}$, and abruptly drop to 0 .

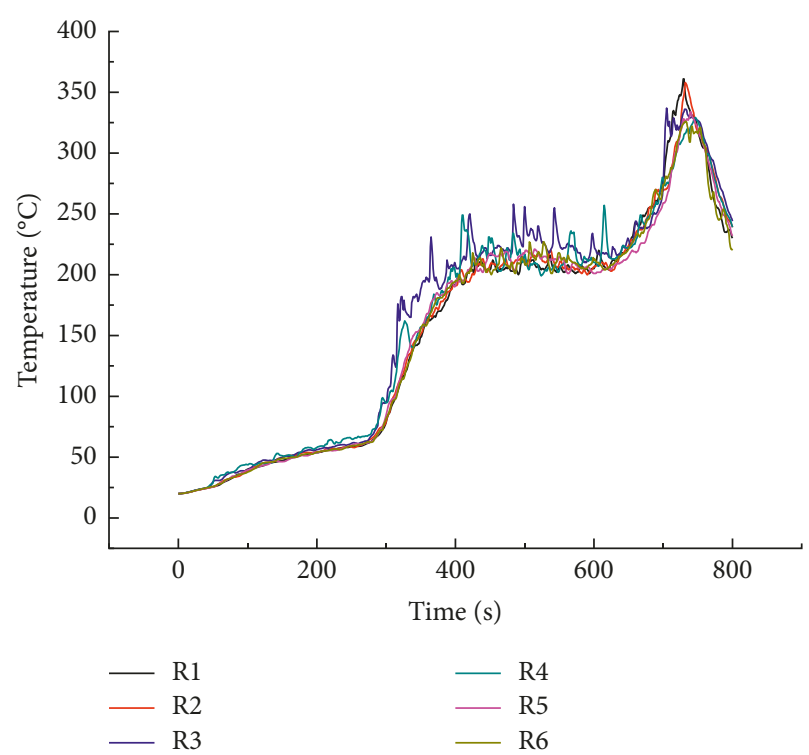

Figure 8: Temperature in case 4.

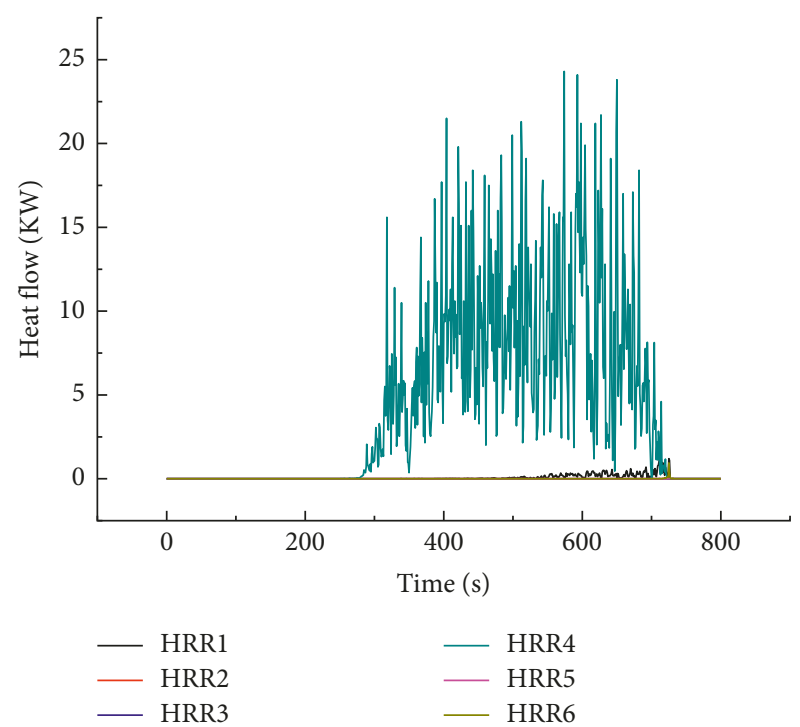

Figure 9: Heat flow density in case 4.

At the simulation time of $320 \mathrm{~s}$, the indoor fire spreads out through windows and skylights, which led to an increase in the heat flow densities of the roof areas near the window (regions near HRR1 and HRR4) until 720 s, at which point the indoor fire reaches its peak. However, the roof waterproofing and insulation layers were not ignited yet, and there was no naked light on the building roof. Therefore, in other areas of the roof, the heat flow densities are close to zero, and the temperatures are low.

The heat flow in case 5 has the same change trend as in case 4 . The temperature in case 5 was higher than that in case 4 , and the highest temperature was above $500^{\circ} \mathrm{C}$. There was no naked light on the building roof.

In cases 6 and 7, there was no naked light on the roof, and the heat flow densities on the roof were close to 0 . 


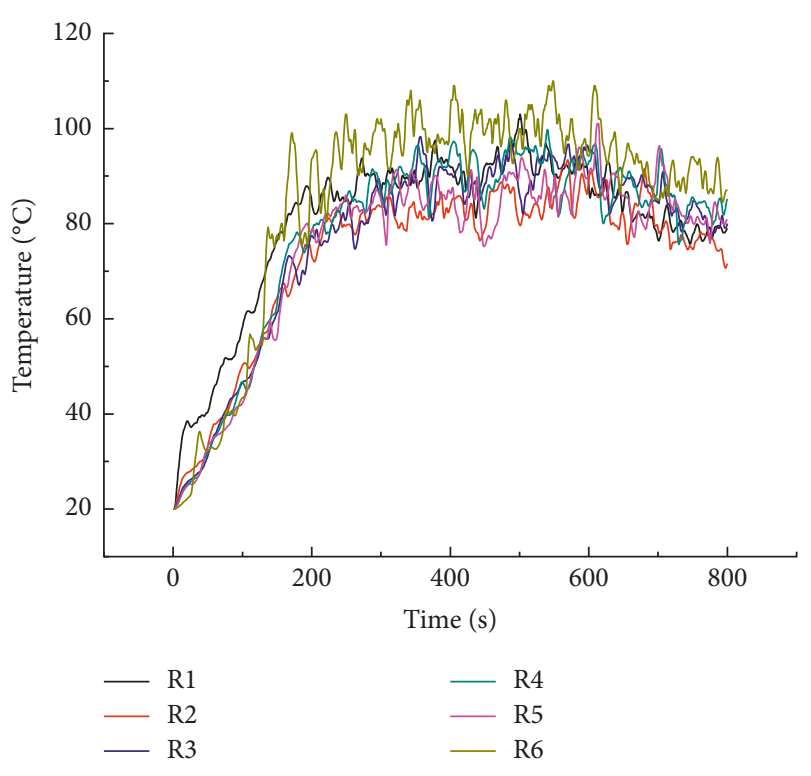

Figure 10: Temperature in case 8.

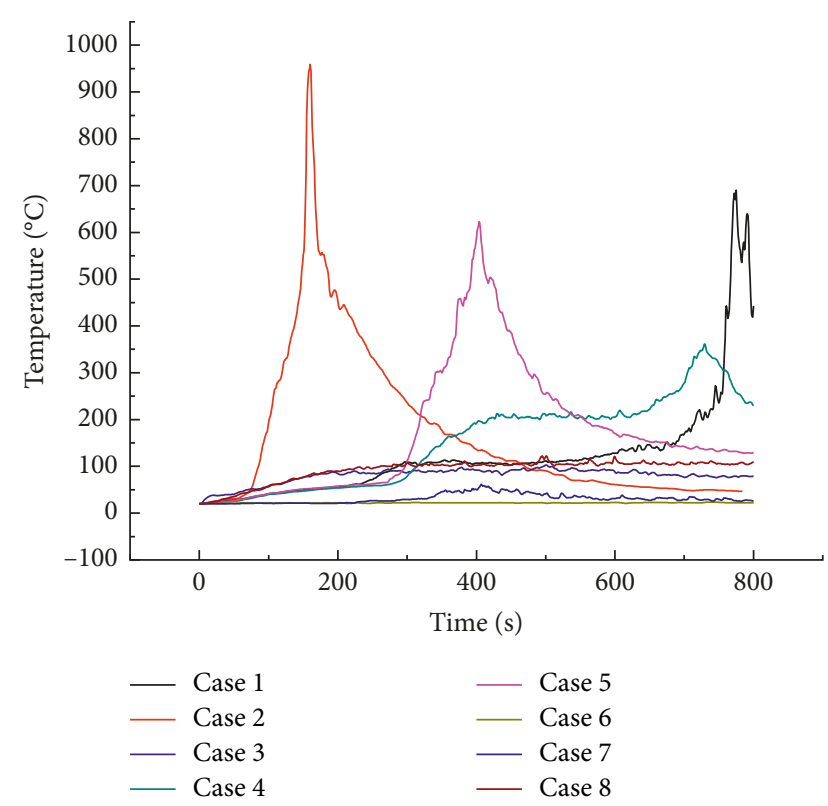

FIgURE 11: Comparison of maximum temperature in eight cases.

Accordingly, the roof temperatures were lower than $50^{\circ} \mathrm{C}$ in case 6, and the highest temperatures of most areas of the roof were lower than $350^{\circ} \mathrm{C}$ in case 7 .

In case 8 , the heat flow densities of most areas of the roof were close to 0 , and the waterproofing and insulation layers were not ignited, as shown in Figure 10; the roof temperature was less than $140^{\circ} \mathrm{C}$.

Comparisons of the roof temperatures and heat flow densities of these cases are shown in Figures 11 and 12.

As shown in Figure 11, the roof temperatures in cases 1,2, 4 , and 5 were higher, especially, the roof temperature in case 2 , which peaked at nearly $1000^{\circ} \mathrm{C}$. According to Figure 12 , in case 2 , the heat flow density on the roof increased rapidly and peaked at close to $300 \mathrm{~kW} / \mathrm{m}^{2}$ when the roof temperature

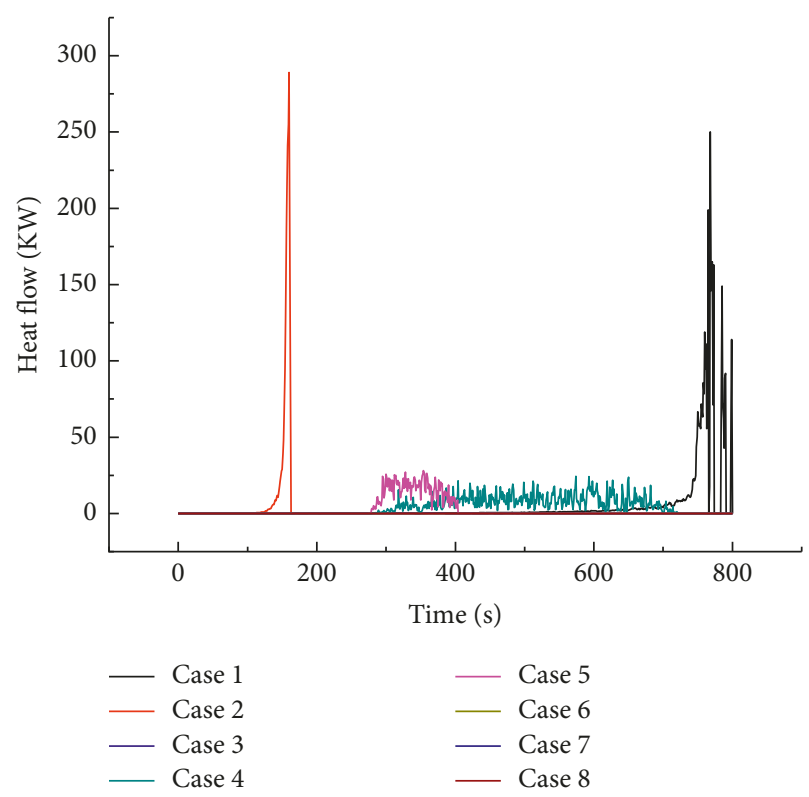

Figure 12: Comparison of maximum heat flow in eight cases.

reached its maximum value. This means that the roof was ignited in case 2 . In addition, the phase from the beginning to the time when the temperature and heat flow reached their maximum values was the shortest, which means that the roof ignited quickly in case 2. From Figures 11 and 12, it is clear that when the roof was ignited in case 1, the roof temperature and heat flow density increased rapidly and peaked. As shown in the figures, although the roof temperatures are high in cases 4 and 5, the roof heat flow densities are low because the roof is not ignited, as stated in the analysis in the preceding part of the text. The temperature near the window and skylight is high because the heat of the indoor fire spread to the roof through the opening. In cases $3,6,7$, and 8 , the roof temperatures are lower than $100^{\circ} \mathrm{C}$, heat flow densities are 0 , and the effect of the fire on the photovoltaic systems is diminished.

Compared to the roof temperatures and heat flow densities in cases 2 and 4, those in cases 1, 5, 6, and 7 are higher, and their influences on the photovoltaic systems are stronger in the case of a fire in a flat-roofed building than that in the case of a sloped-roofed building. Based on a comparison of cases 1,2, and 3 and a comparison of cases $4,5,6,7$, and 8 , indoor fire in a building ignites the roof more easily, and the possibility of the fire engulfing photovoltaic systems is greater. A comparison of cases 4, 5, 6, and 7 shows that, in a sloping-roofed building with a skylight, an indoor fire spreads more easily to the roof and ignites photovoltaic systems on the roof compared to that in a sloping-roofed building with no skylight. A comparison of cases 1 and 2 shows that a fire of the external wall thermal insulation ignites the roof more easily. A comparison of cases 4 and 5 shows that when the external wall thermal insulation of building is on fire, the roof temperature is higher, and the influence of the external wall thermal insulation building fire on photovoltaic systems is stronger. 


\section{Conclusions and Suggestions}

4.1. Conclusions. The values of roofing heat flow density and temperature depend on whether the roof is ignited and a skylight is present, magnitude of heat flow density, and magnitude of roof temperature. If roof temperature and heat flow density are high, the photovoltaic systems on the roof are at great risk.

(1) Compared with fires in sloping-roofed buildings, fires in flat-roofed buildings have stronger adverse effects on photovoltaic systems. When the exposed waterproofing and thermal insulation material in a flatroofed building fire is ignited, the roofing temperature increases more than $750^{\circ} \mathrm{C}$, roof heat flow density more than $260 \mathrm{~kW} / \mathrm{m}^{2}$, and any photovoltaic systems on the roof are more likely to ignite.

(2) In case of a fire on a sloping-roofed building, because there are protective layers such as ceramic tiles and there is no naked light on the roof, heat flow density is smaller than $1 \mathrm{~kW} / \mathrm{m}^{2}$, and the possibility of photovoltaic systems igniting is small. However, the roof temperature is higher than $450^{\circ} \mathrm{C}$ when there is a skylight, and the photovoltaic systems on a slopingroofed building with a skylight are more susceptible to ignition.

(3) Relative to fires of the internal wall thermal insulation of buildings, fires of the external wall thermal insulation of buildings have a greater influence on photovoltaic systems.

4.2. Suggestions. Photovoltaic buildings are severely impacted by building fires. With the vigorous development of the photovoltaic industry, along with the great importance accorded to photovoltaic power generation efficiency, we should focus on improving the safety of photovoltaic systems. First, we should take roof fires seriously, use noncombustible or flame-resistant materials for waterproofing and insulation materials to the extent possible, and issue related standards in a timely manner, such as fire safety rules specific to photovoltaic buildings. Moreover, capabilities for preventing and controlling fires of photovoltaic systems should be strengthened by providing professional training to the firefighting staff.

\section{Conflicts of Interest}

The authors declare that they have no conflicts of interest.

\section{Acknowledgments}

This work was supported by the National Natural Science Foundation of China under Grant no. 51678390.

\section{References}

[1] Law of the People's Republic of China on Regenerable Energies, The fourteenth session of the standing committee of the tenth National People's Congress of the People's Republic of China, 2012.
[2] H. Zhicheng, Application Research on Distributed Photovoltaic Power Generation System, Tianjin Chengjian University, vol. 6, Tianjin, China, 2013.

[3] B. Peter Jelle, C. Breivik, and H. Drolsum Rokenes, "Building integrated photovoltaic products: a state-of-the-art review and future research opportunities," Solar Energy Materials and Solar Cells, vol. 100, pp. 69-96, 2012.

[4] H. Y. Yang, X. D. Zhou, L. Z. Yang, and T.-L. Zhang, "Experimental studies on the flammability and fire hazards of photovoltaic modules," Materials, vol. 8, no. 7, pp. 4210-4225, 2015.

[5] M. J. Spearpoint and J. G. Quintiere, "Predicting the piloted ignition of wood in the cone calorimeter using an integral model-effect of species, grain orientation and heat flow," Fire Safety Journal, vol. 36, no. 4, pp. 391-415, 2001.

[6] K. Murata, T. Yagiura, K. Takeda, M. Tanaka, and S. Kiyama, "New type of photovoltaic module integrated with roofing material (highly fire-resistant PV tile)," Solar Energy Materials and Solar Cells, vol. 75, no. 3-4, pp. 647-653, 2002.

[7] F. Jun, "Prevention technology photovoltaic power station fire risk," Application Technology, vol. 4, 2016.

[8] GB 50016-2014, Code of Design on Building Fire Protection and Prevention, Ministry of housing and urban-rural development of the People's Republic of China, Beijing, China, 2014.

[9] GB 50229-2006, Code for Design of Fire Protection for Fossil Fuel Power Plants and Substations, Ministry of housing and urban-rural development of the People's Republic of China, Beijing, China, 2014.

[10] GB 50797-2012, Code for Design of Fire Protection for Photovoltaic Power Station, Ministry of housing and urban-rural development of the People's Republic of China, Beijing, China, 2014.

[11] Z. Dongqing and Z. Zhiyuan, "Discussion on the ways of fire prevention technology of roof engineering in China," $C B W$ Roofing Engineering, vol. 7, pp. 1-36, 2012.

[12] M. Qianli and N. Zhaopeng, "Some views on fire resistance of roofs," CBW-Roofing Engineering, vol. 3, pp. 7-10, 2011.

[13] V. Lysenko, P. Roussel, B. Remaki et al., "Study of nanoporous silicon with low thermal conductivity as thermal insulating material," Journal of Porous Materials, vol. 1, 2000.

[14] B. F. Magnussen and B. H. Hjertager, "On mathematical modeling of turbulent combustion with special emphasis on soot formation and combustion," in Proceedings of the Sixteenth Symposium (International) on Combustion, pp. 719729, Combustion Institute, Pittsburgh, PA, USA, 1977.

[15] R. O. Fox, Computational Models for Turbulent Reacting Flows, Cambridge Univ Press, Cambridge, UK, 2003.

[16] L. Orloff and J. de Ris, "Froude modeling of pool fires," in Proceedings of the Nineteenth Symposium (International) on Combustion, pp. 885-895, Combustion Institute, Pittsburgh, PA, USA, 1982.

[17] GB 50693-2014, Technical Code for Slope Roof Engineering, Ministry of housing and urban-rural development of the People's Republic of China, Beijing, China, 2014.

[18] GB 50345-2012, Technical Code for Roof Engineering, Ministry of housing and urban-rural development of the People's Republic of China, Beijing, China, 2014. 


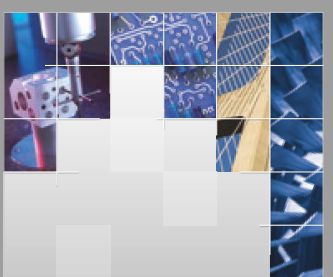

\section{Enfincering}
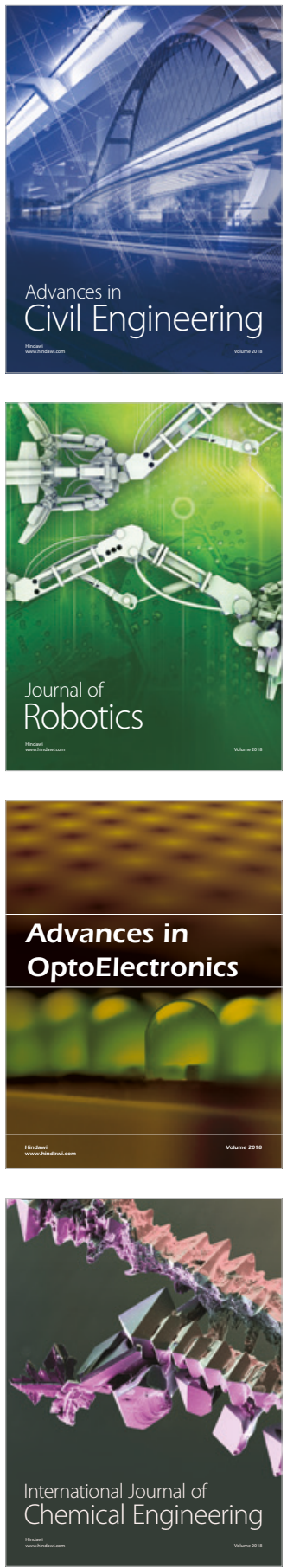

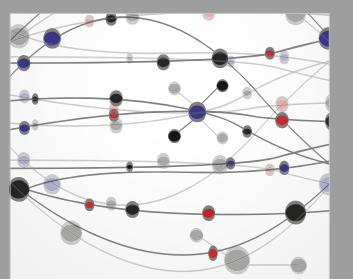

\section{Rotating \\ Machinery}

The Scientific World Journal

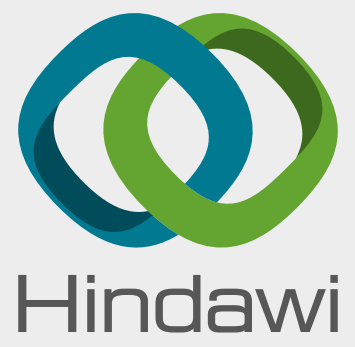

Submit your manuscripts at

www.hindawi.com
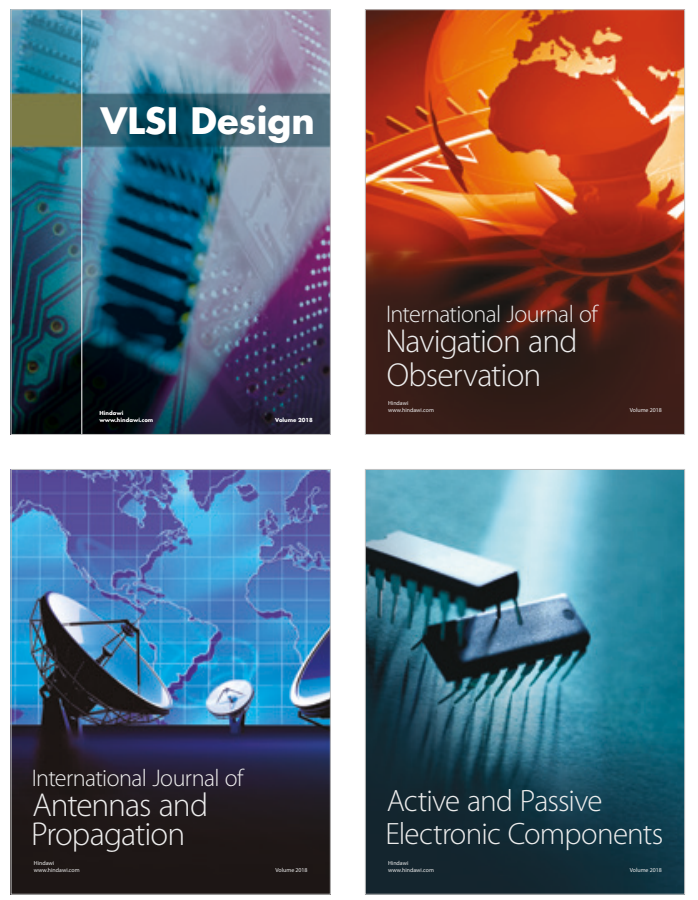
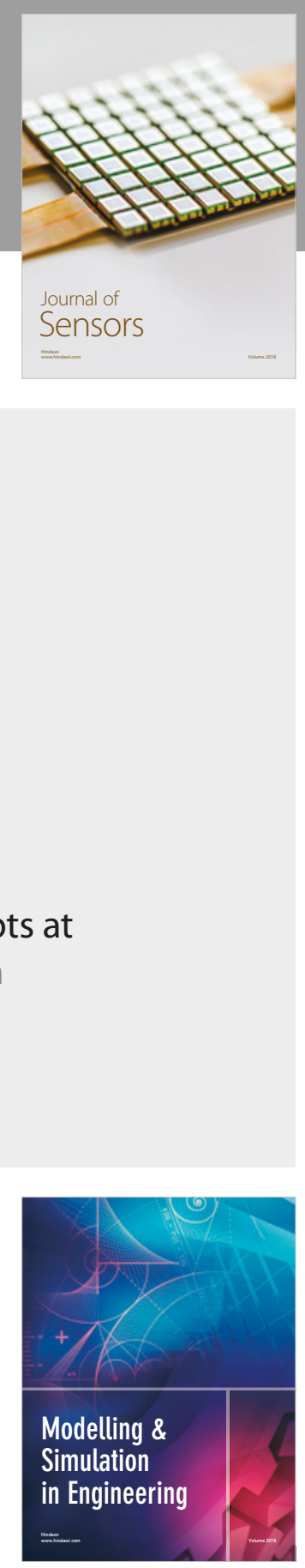

\section{Advances \\ Multimedia}
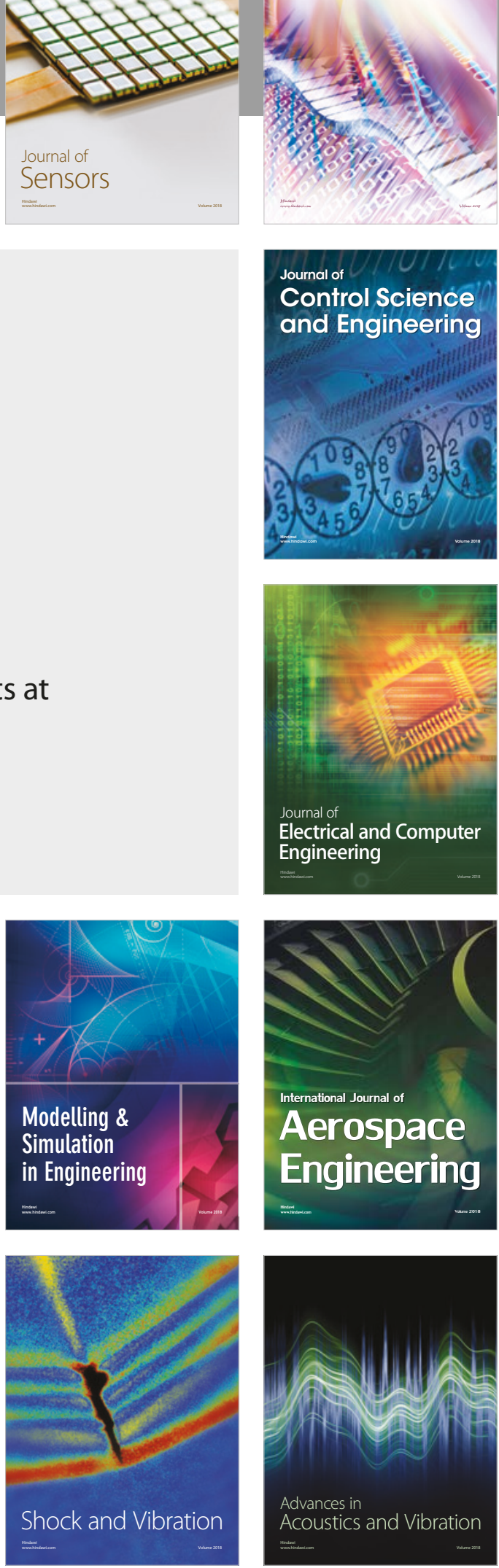